\title{
KEUNGGULAN BERSAING DITINJAU DARI GREEN MARKETING, SIKAP KONSUMEN DAN KUALITAS PRODUK (Studi Pada Indomilk Surakarta)
}

\author{
Muhammad Ainun Najib ${ }^{1}$ Istiatin $^{2}$, Ratna Damayanti ${ }^{3}$ \\ Islam Batik University of Surakarta \\ Email : ainunnajib97@gmail.com
}

\begin{abstract}
The research aims to find out and describe the influence of simultaneously or partial green marketing, attitude and product quality towards competitive advantage in Indomilk Surakarta. This methodology research using quantitative descriptive research. The population was all consumers Indomilk Surakarta is unknown number. The number of samples was determined with the formula Lemeshow and the result 100 respondents. Sampling method using convenience sampling. The questionnaire used for data retrieval. Data analysis technique used was statistic analysis is multiple linier regression, $F$ test, $t$ test and determination coefficient. This test results the green marketing, attitude and product quality simultaneously and significance effect on competitive advantage in Indomilk Surakarta. Green marketing influential positive and significance effect against the competitive advantage in Indomilk Surakarta. Attitude influential positive and significance effect against the competitive advantage in Indomilk Surakarta. Product quality influential positive and significance effect against the competitive advantage in Indomilk Surakarta.
\end{abstract}

Keywords : Competitive Advantage, Green Marketing, Attitude, Product Quality

\section{PENDAHULUAN}

Perusahaan membutuhkan strategi khusus yang harus diterapkan untuk mempertahankan konsumen. Salah satunya dengan menerapkan strategi untuk meningkatkan keunggulan bersaing. Pada dasarnya konsumen lebih tertarik dan memilih perusahaan yang memiliki daya saing lebih unggul dibandingkan dengan perusahan lain. Perusahaan akan melakukan berbagai strategi dengan kebijakan yang akan digunakan agar tujuan tercapai. Keunggulan bersaing menjadi strategi yang dilakukan perusahaan untuk menciptakan atau memberi nilai lebih kepada konsumen.

Green marketing menjadi salah satu faktor yang dapat mempengaruhi keunggulan bersaing sebuah perusahaan. Green marketing tidak hanya sekedar memasarkan produk ramah lingkungan, tetapi menuntut adanya suatu orientasi dan tanggung jawab lingkungan. Green marketing berpengaruh signifikan terhadap keunggulan bersaing (Widiarsa \& Sulistyawati, 2018). Perusahaan menggunakan green marketing untuk meningkatkan brand image yang lebih ramah lingkungan. Strategi ini akan berpengaruh pada keunggulan perusahaan dalam bersaing dengan perusahaan lain dan dapat meningkatkan minat beli masyarakat.

Selain green marketing, sikap konsumen juga dapat menjadi salah satu faktor keunggulan bersaing. Sikap sangat erat kaitannya dengan perasaan konsumen dan dapat mempengaruhi terhadap perilaku untuk membeli suatu produk. Sikap konsumen berpengaruh signifikan terhadap keunggulan bersaing (Wahyudin, 2015). Sikap konsumen memiliki peranan cukup penting bagi perusahaan dengan memberikan kepercayaan merek yang kuat kepada konsumen, maka dapat meningkatkan keunggulan bersaing.

Kualitas produk juga menjadi salah satu strategi yang dapat dilakukan oleh perusahaan untuk menjadi unggul dalam persaingan. Mencapai kualitas produk yang diinginkan maka 
diperlukan suatu standarisasi. Konsumen tidak akan kehilangan kepercayaan terhadap produk yang bersangkutan. Kualitas produk berpengaruh signifikan terhadap keunggulan bersaing (Christian, 2017). Kualitas produk harus dijaga dengan baik, semakin baik kualitas produk maka konsumen akan semakin berminat untuk membeli dan dapat menjadi strategi perusahaan dalam mempertahankan keunggulan bersaing.

PT. Indomarco Hco Surakarta beralamatkan di Silamat, Ngringo, Jaten, Kabupaten Karanganyar. Perusahaan bergerak di bidang distributor consumer product. Indomilk menjadi salah satu produk yang didistribusikan oleh PT. Indomarco Hco Surakarta. Adanya fenomena kompetitor yang memiliki daya saing lebih unggul menjadi salah penyebab terjadinya fluktuasi penjualan. Masyarakat lebih memilih membeli produk dari perusahaan lain. Tumbuhnya pesaing yang semakin unggul membuat perusahaan mengalami hambatan dalam meningkatkan maupun mempertahankan pangsa pasar. Perusahaan terus berupaya untuk dapat meraih hati konsumen, salah satunya dengan melakukan green marketing. Perusahaan merubah kemasan Indomilk menjadi lebih ramah lingkungan. Kemasan tersebut lebih mudah untuk dihancurkan setelah pemakaian. Adanya respon konsumen yang cukup baik dengan adanya kemasan yang ramah lingkungan belum mampu membawa Indomilk menguasai pangsa pasar. Berdasarkan hasil wawancara awal dengan konsumen, adanya sikap konsumen yang menunjukkan kepercayaan terhadap merek membuat perusahaan mampu bertahan pada persaingan yang semakin ketat. Konsumen juga mengetahui manfaat yang diberikan setelah meminum Indomilk. Selain itu, adanya perkembangan ilmu pengetahuan dan teknologi yang semakin canggih membuat produk yang dihasilkan Indomilk memiliki kualitas yang lebih baik dari produk pesaing. Jika dilihat dari manfaat, memiliki fungsi yang sama, namun rasa yang dihasilkan oleh susu Indomilk nyatanya lebih enak dibanding produk pesaing.

Berdasarkan uraian di atas, penulis tertarik untuk melakukan penelitian dengan judul Keunggulan Bersaing ditinjau dari Green Marketing, Sikap Konsumen dan Kualitas Produk (Studi Pada Indomilk Surakarta).

Adapun tujuan yang ingin dicapai dalam penelitian ini adalah mengetahui dan menjelaskan green marketing, sikap konsumen dan kualitas produk secara simultan berpengaruh terhadap keunggulan bersaing pada Indomilk Surakarta. Mengetahui dan menjelaskan green marketing berpengaruh terhadap keunggulan bersaing pada Indomilk Surakarta. Mengetahui dan menjelaskan sikap konsumen berpengaruh terhadap keunggulan bersaing pada Indomilk Surakarta. Mengetahui dan menjelaskan kualitas produk berpengaruh terhadap keunggulan bersaing pada Indomilk Surakarta.

\section{LANDASAN TEORI}

Keunggulan bersaing pada dasarnya tumbuh dari manfaat yang dapat diciptakan perusahaan bagi para pembeli lebih dari biaya harus dikeluarkan perusahaan. Manfaat inilah yang sedia dibayar oleh pembeli berasal dari penawaran harga lebih rendah ketimbang harga pesaing. Tjiptono (2018: 13) keunggulan bersaing sebagai suatu yang memungkinkan perusahaan untuk memperoleh laba lebih tinggi dari rata-rata. Dirgantoro (2016: 13) keunggulan bersaing adalah perkembangan nilai yang mampu diberikan perusahaan kepada konsumen. Keunggulan bersaing perlu dimiliki perusahaan untuk menciptakan nilai kepercayaan konsumen. Keunggulan bersaing tercipta dengan adanya kompetensi setara, perusahaan mampu menciptakan perbedaan dan menciptakan faktor-faktor kritis untuk kesuksesan industri. Kotler dan Armstrong (2015: 93) keunggulan bersaing adalah kemampuan perusahaan melakukan dengan baik satu atau lebih cara yang tidak dapat atau tidak akan ditandingi para pesaing. 
Green marketing adalah suatu proses pemasaran produk-produk yang diasumsikan aman terhadap lingkungan (David, 2017: 62). Green marketing dapat dikatakan tidak sekedar menawarkan produk yang hanya ramah lingkungan, tetapi juga mencakup proses produksi, pergantian packaging serta aktivitas modifikasi produk (Triton, 2016: 86). Green marketing sebagai aplikasi dari alat pemasaran untuk memfasilitasi perubahan yang memberikan kepuasan organisasi dan tujuan individual dalam melakukan pemeliharaan, perlindungan dan konservasi pada lingkungan fisik (Alma, 2015: 138).

Schiffman dan Kanuk (2014: 222) sikap konsumen adalah kecenderungan yang dipelajari dalam berperilaku dengan cara yang menyenangkan atau tidak menyenangkan terhadap suatu produk tertentu. Sikap merupakan konsep paling penting dalam studi perilaku konsumen, dengan mempengaruhi sikap, pemasar berharap dapat mempengaruhi perilaku pembelian (Simamora, 2014: 152). Kotler dan Armstrong (2015: 176) sikap menggambarkan evaluasi dan perasaan dari seseorang terhadap sebuah objek atau ide. Sikap menempatkan orang ke dalam suatu kerangka pikiran untuk menyukai atau tidak menyukai sesuatu, untuk bergerak menuju atau meninggalkan sesuatu.

Kotler dan Amstrong (2015: 184) kualitas produk adalah kemampuan sebuah produk dalam memperagakan fungsi, termasuk keseluruhan durabilitas, reliabilitas, ketepatan, kemudahan pengoperasian dan reparasi produk juga atribut produk . Kualitas produk adalah suatu kondisi dinamis yang berhubungan dengan produk, manusia/tenaga kerja, proses dan tugas serta lingkungan yang memenuhi atau melebihi harapan konsumen (Nasution, 2015: 46). Tjiptono (2018: 112) kualitas produk sebagai tingkat mutu yang diharapkan dan pengendalian keragaman dalam mencapai mutu tersebut untuk memenuhi kebutuhan konsumen.

\section{METODOLOGI PENELITIAN}

Penelitian ini menggunakan penelitian kuantitatif. Penelitian ini dilakukan di Surakarta. Populasi dalam penelitian ini adalah seluruh konsumen yang melakukan pembelian produk Indomilk di Surakarta yang jumlahnya tak terhingga. Jumlah populasinya tak terhingga maka untuk menentukan sampelnya dengan menggunakan rumus Lemeshow (Sugiyono, 2016: 84) sebagai berikut:

$$
\begin{aligned}
& \mathrm{n}=\frac{\mathrm{Z}^{2} \cdot \mathrm{p} \cdot \mathrm{q}}{\mathrm{d}^{2}} \\
& \text { Keterangan: } \\
& \mathrm{n}=\text { Jumlah sampel. } \\
& \mathrm{Z}=\text { Harga standar normal }(1,96) \\
& \mathrm{p}=\text { Estimator proporsi populasi }(0,5) \\
& \mathrm{d}=\text { Interval/penyimpangan }(0,10) \\
& \mathrm{q}=1-\mathrm{p} \\
& \text { Jadi besar sampel dapat dihitung sebagai berikut: } \\
& \mathrm{n}=\frac{(1,96)^{2}(0,5)(0,5)}{(0,10)^{2}}=97,6 \text { dibulatkan menjadi } 100 \text { responden }
\end{aligned}
$$

Teknik sampling menggunakan metode convenience sampling yaitu pengambilan sampel didasarkan pada ketersediaan elemen dan kemudahan untuk mendapatkannya karena ada pada tempat dan waktu yang tepat (Sugiyono, 2016: 22). Kuesioner digunakan untuk pengambilan data. Regresi linier berganda sebagai metode untuk menganalisis data. 


\section{HASIL DAN PEMBAHASAN}

\section{Uji Asumsi Klasik}

\section{Hasil uji normalitas}

Menguji normalitas digunakan alat analisis Kolmogorov Smirnov, hasilnya adalah:

Tabel 1. Hasil Uji Normalitas

\begin{tabular}{lcc}
\hline & $\begin{array}{c}\text { Unstandardized } \\
\text { Residual }\end{array}$ & Keterangan \\
\hline$N$ & 100 & Data terdistribusi \\
Kolmogorov-Smirnov $Z$ & 0,892 & normal \\
Asymp.Sig.(2-tailed) & 0,403 & \\
\hline
\end{tabular}

Hasil pengujian Kolmogrov Smirnov test menunjukkan bahwa nilai Asymp. Sig (2-tailed) lebih besar dari 0,05 (0,403>0,05). Menunjukkan bahwa persamaan regresi untuk model dalam penelitian ini memiliki sebaran data yang normal.

\section{Hasil uji multikolinearitas}

Hasil yang di dapatkan dalam uji multikolinearitas adalah:

Tabel 2. Hasil Uji Multikolinearitas

\begin{tabular}{|c|c|c|c|}
\hline \multirow[t]{2}{*}{ Model } & \multicolumn{2}{|c|}{ Collinearity Statistics } & \multirow[t]{2}{*}{ Keterangan } \\
\hline & Tolerance & $V I F$ & \\
\hline Green Marketing & 0,494 & 2,023 & $\begin{array}{c}\text { Tidak terjadi } \\
\text { multikolinearitas }\end{array}$ \\
\hline Sikap Konsumen & 0,898 & 1,114 & $\begin{array}{c}\text { Tidak terjadi } \\
\text { multikolinearitas }\end{array}$ \\
\hline Kualitas Produk & 0,461 & 2,168 & $\begin{array}{c}\text { Tidak terjadi } \\
\text { multikolinearitas }\end{array}$ \\
\hline
\end{tabular}

Berdasarkan hasil perhitungan pada tabel di atas, diperoleh nilai tolerance variabel green marketing 0,494, nilai tolerance variabel sikap konsumen 0,898 dan nilai tolerance variabel kualitas produk 0,461 , yang semuanya $>0,10$. Jadi model regresi pada penelitian ini tidak ada multikolinearitas antar variabel bebas.

\section{Hasil uji heteroskedastisitas}

Hasil yang di dapatkan dalam uji heteroskedastisitas adalah:

Tabel 3. Hasil Uji Heteroskedastisitas

\begin{tabular}{lcc}
\hline \multicolumn{1}{c}{ Model } & Sig. & Keterangan \\
\hline Green Marketing & 0,931 & Tidak terjadi heterokedastisitas \\
Sikap Konsumen & 0,845 & Tidak terjadi heterokedastisitas \\
Kualitas Produk & 0,110 & Tidak terjadi heterokedastisitas \\
\hline
\end{tabular}

Berdasarkan tabel di atas menunjukkan bahwa nilai probabilitas (Sig.) dari masing-masing variabel independen adalah green marketing bernilai 0,931, sikap konsumen bernilai 0,845 dan kualitas produk bernilai 0,110 yang ke semuanya lebih besar dari 0,05. Dapat dinyatakan model regresi ini tidak terjadi heteroskedastisitas. 


\section{Uji Hipotesis}

\section{Hasil regresi linier berganda}

Nilai a dan $b_{1}, b_{2}, b_{3}$ dalam uji regresi linier berganda adalah:

\begin{tabular}{lcc}
\multicolumn{2}{c}{ Tabel 4. Analisis Regresi Linier Berganda } \\
\hline \multicolumn{1}{c}{ Model } & \multicolumn{2}{c}{$\begin{array}{l}\text { Unstandarized } \\
\text { coefficients }\end{array}$} \\
& B & Std. \\
& & Error \\
\hline Constant & 0,114 & 1,839 \\
Green Marketing & 0,424 & 0,098 \\
Sikap Konsumen & 0,181 & 0,075 \\
Kualitas Produk & 0,361 & 0,069 \\
\hline
\end{tabular}

Berdasarkan persamaannya adalah:

$\mathrm{Y}=0,114+0,424 \mathrm{X}_{1}+0,181 \mathrm{X}_{2}+0,361 \mathrm{X}_{3}+\mathrm{e}$

\section{Hasil uji F}

Perhitungan nilai $F_{h i t u n g}$ adalah:

Tabel 5. Hasil Uji F

\begin{tabular}{lccc}
\hline \multicolumn{1}{c}{ Model } & $F$ & Sig. & Keterangan \\
\hline Regressio & 63,164 & 0,000 & $\mathrm{H}_{0}$ ditolak, $\mathrm{H}_{1}$ diterima \\
$n$ & & & \\
Residual & & & \\
Total & & & \\
\hline
\end{tabular}

Hasil analisis data yang telah didapatkan, maka dapat diketahui bahwa nilai $F_{\text {hitung }}$ adalah sebesar 63,164, dikarenakan $F_{\text {hitung }}>F_{\text {tabel }}(63,164>2,70)$ dan signifikansi $0,000<0,05$ maka Ho ditolak. Dapat disimpulkan $\mathrm{H}_{1}$ diterima, artinya ada pengaruh antara green marketing, sikap konsumen dan kualitas produk secara simultan dan signifikan terhadap keunggulan bersaing pada Indomilk di Surakarta.

\section{Hasil uji t}

Perhitungan uji thitung adalah:

Tabel 6. Hasil Uji t

\begin{tabular}{cccrl}
\hline Model & $\mathrm{B}$ & $\mathrm{t}$ & Sig. & Keterangan \\
\hline Green Marketing & 0,424 & 4,316 & 0,00 & $\mathrm{H}_{2}$ diterima \\
& & & 0 & \\
Sikap Konsumen & 0,181 & 2,433 & 0,01 & $\mathrm{H}_{3}$ diterima \\
& & & 7 & \\
Kualitas Produk & 0,361 & 5,241 & 0,00 & $\mathrm{H}_{4}$ diterima \\
& & & 0 & \\
\hline
\end{tabular}

Nilai $\mathrm{t}_{\text {hitung }}>\mathrm{t}_{\text {tabel }}(4,316>1,985)$ dan nilai signifikansi $0,000<0,05$ maka Ho ditolak dan $\mathrm{H}_{2}$ diterima. Dapat disimpulkan bahwa ada pengaruh positif dan signifikan green marketing terhadap keunggulan bersaing pada Indomilk di Surakarta. 
Nilai $t_{\text {hitung }}>\mathrm{t}_{\text {tabel }}(2,433>1,985)$ dan nilai signifikansi $0,017<0,05$ maka Ho ditolak dan $\mathrm{H}_{3}$ diterima. Dapat disimpulkan bahwa ada pengaruh positif dan signifikan sikap konsumen terhadap keunggulan bersaing pada Indomilk di Surakarta.

Nilai $t_{\text {hitung }}>\mathrm{t}_{\text {tabel }}(5,241>1,985)$ dan nilai signifikansi $0,000<0,05$ maka Ho ditolak dan $\mathrm{H}_{4}$ diterima. Dapat disimpulkan bahwa ada pengaruh positif dan signifikan kualitas produk terhadap keunggulan bersaing pada Indomilk di Surakarta.

\section{Hasil uji koefisien determinasi}

Perhitungan nilai koefisien determinasi adalah:

Tabel 7.

Hasil Koefisien Determinasi

\begin{tabular}{ccc}
\hline$R$ & $R$ Square & Adjusted $R$ Square \\
\hline 0,815 & 0,664 & 0,653 \\
\hline
\end{tabular}

Berdasarkan hasil analisis di atas maka diperoleh nilai Adjusted $R$ Square sebesar 0,653 atau $65,3 \%$. Determinasi atau sumbangan variabel green marketing, sikap konsumen dan kualitas produk terhadap keunggulan bersaing pada Indomilk di Surakarta sebesar 65,3\%. Sisanya sumbangan variabel-variabel lain hanya sebesar $34,7 \%$ seperti biaya rendah, diferensiasi, fokus, kepeloporan, sinergi dan lain-lain.

\section{PEMBAHASAN}

Berdasarkan hasil uji $\mathrm{F}$ maka diketahui $\mathrm{F}_{\text {hitung }}>\mathrm{F}_{\text {tabel }}(63,164>2,70)$ dan signifikansi 0,000 $<0,05$, maka Ho ditolak $\mathrm{H}_{1}$ diterima. Artinya green marketing, sikap konsumen dan kualitas produk secara simultan dan siginifikan berpengaruh terhadap keunggulan bersaing. Hasil tersebut membuktikan semakin tinggi green marketing, sikap konsumen dan kualitas produk maka pada keunggulan bersaing akan mengalami peningkatan secara nyata

Berdasarkan analisis uji $t$ diperoleh hasil nilai $t_{\text {hitung }}>t_{\text {tabel }}(4,316>1,985)$, nilai signifikansi $0,000<0,05$ dan koefisien regresi mempunyai nilai positif sebesar 0,424 , maka Ho ditolak $\mathrm{H}_{2}$ diterima. Artinya green marketing berpengaruh positif dan signifikan terhadap keunggulan bersaing. Apabila green marketing yang ada semakin tinggi, maka keunggulan bersaing akan meningkat. Green marketing berpengaruh terhadap keunggulan bersaing Pada Indomilk di Surakarta karena perusahaan menggunakan kemasan yang lebih ramah lingkungan, mudah dihancurkan setelah pemakaian. Strategi pemasaran yang dilakukan oleh Indomilk dengan meningkatkan kualitas promosi yang berhubungan dengan nilai-nilai lingkungan untuk mengangkat produk Indomilk sebagai produk berbahan alami dan ramah lingkungan. Indomilk terus mengkomunikasikan kegiatan kampanye yang dilakukan, menyampaikan pesan lingkungan dan produk Indomilk. Memberikan pemahaman tentang lingkungan disosialisasikan secara langsung oleh pemasar tidak hanya terfokus pada kualitas produk akan tetapi membahas hubungannya produk dengan lingkungan. Sehingga konsumen bisa menyadari susu Indomilk mengandung bahan baku alami dan kemasan yang digunakan ramah lingkungan. Penelitian ini sejalan dengan penelitian sebelumnya yang dilakukan oleh Widiarsa dan Sulistyawati (2018) green marketing berpengaruh positif dan signifikan terhadap keunggulan bersaing.

Berdasarkan analisis uji $t$ diperoleh hasil nilai $t_{\text {hitung }}>\mathrm{t}_{\text {tabel }}(2,433>1,985)$, nilai signifikansi $0,017<0,05$ dan koefisien regresi mempunyai nilai positif sebesar 0,181 , maka Ho ditolak $\mathrm{H}_{2}$ diterima. Artinya sikap konsumen berpengaruh positif dan signifikan terhadap keunggulan bersaing. Apabila sikap konsumen yang ada semakin tinggi, maka akan meningkatkan 
keunggulan bersaing. Sikap konsumen berpengaruh terhadap keunggulan bersaing pada Indomilk di Surakarta. Adanya sikap konsumen yang menunjukkan kepercayaan terhadap merek membuat perusahaan mampu bertahan pada persaingan yang semakin ketat. Konsumen juga mengetahui manfaat yang diberikan setelah meminum susu Indomilk, dapat menjaga kesehatan dan kebugaran tubuh. Konsumen lebih berminat membeli susu Indomilk karena sebagai pelopor minuman susu kemasan. Konsumen loyal terhadap susu Indomilk karena mengandung vitamin A, B1, B6, D, Prebiotik, Kolin, Kalsium, Protein dan Antioksidan. Konsumen juga menyukai susu Indomilk dengan rasa yang enak. Konsumen minum susu Indomilk untuk menjaga kesehatan tubuh. Adanya sikap konsumen yang loyal terhadap susu Indomilk menjadi salah satu keunggulan perusahaan dalam memenangkan persaingan dalam meraih pangsa pasar. Penelitian ini sejalan dengan penelitian sebelumnya yang dilakukan oleh Wahyudin (2015) sikap konsumen berpengaruh secara positif dan signifikan terhadap keunggulan bersaing.

Berdasarkan analisis uji $t$ diperoleh hasil nilai $t_{\text {hitung }}>\mathrm{t}_{\text {tabel }}(5,241>1,985)$, nilai signifikansi $0,000<0,05$ dan koefisien regresi mempunyai nilai positif sebesar 0,361 , maka Ho ditolak $\mathrm{H}_{4}$ diterima. Artinya kualitas produk berpengaruh positif dan signifikan terhadap keunggulan bersaing. Apabila kualitas produk yang ada semakin meningkat, maka akan meningkatkan keunggulan bersaing. Kualitas produk berpengaruh terhadap keunggulan bersaing pada Indomilk di Surakarta. Proses produksi yang menggunakan teknologi mutakhir dan praktek sterilisasi dari awal hingga akhir untuk menghindari terjadinya kontaminasi. Hal ini untuk menjaga agar susu Indomilk memiliki kualitas produk yang baik. Susu Indomilk memiliki sertifikat halal. Susu Indomilk menjadi susu kemasan pertama di Indonesia yang memperoleh rekomendasi untuk mencantumkan label halal pada semua lini produk setelah memenuhi persyaratan ketat dalam hal bahan baku, formula, pengolahan, peralatan, kebersihan sarana kerja, kontrol mutu dan kemasan. Selain itu, susu Indomilk juga mendapatkan piagam Bintang Tiga Keamanan Pangan dari BPOM atas prestasinya dalam menerapkan manajemen keamanan pangan. Perusahaan sangat peduli terhadap mutu produk yang dihasilkan. Perusahaan menerapkan sistem manajemen mutu, keamanan pangan dan jaminan halal dalam rangka menghasilkan produk bermutu, aman dan halal yang dapat memberikan kepuasan konsumen. Susu Indomilk yang berkualitas menjadikan perusahaan memiliki keunggulan bersaing untuk meraih pangsa pasar dan bertahan di tengah persaingan semakin ketat. Penelitian ini sejalan dengan penelitian sebelumnya yang dilakukan Christian (2017) kualitas produk berpengaruh positif dan signifikan terhadap keunggulan bersaing.

\section{KESIMPULAN}

Ada pengaruh simultan dan signifikan green marketing, sikap konsumen dan kualitas produk terhadap keunggulan bersaing pada Indomilk di Surakarta. Green marketing berpengaruh positif dan signifikan terhadap keunggulan bersaing pada Indomilk di Surakarta. Sikap konsumen berpengaruh positif dan signifikan terhadap keunggulan bersaing pada Indomilk di Surakarta. Kualitas produk berpengaruh positif dan signifikan terhadap keunggulan bersaing pada Indomilk di Surakarta. 


\section{DAFTAR PUSTAKA}

Alma, B. (2015). Manajemen Pemasaran dan Pemasaran Jasa. Bandung: Penerbit Alabeta

Arseculeratne, D., \& Yazdanifard, R. (2014). How Green Marketing Can Create a Sustainable Competitive Advantage for a Business. International Business Research 7(1), 130-137

Christian, J. (2017). Pengaruh Kualitas Produk dan Inovasi Produk terhadap Keunggulan Bersaing Pada Clothing Our Bandung Style. Artikel Ilmiah Universitas Komputer Indonesia, 1-13

Crassous, T., \& Gassmann, J. (2012). Gaining Competitive Advantage Through Green Marketing. Journal International Halmstad University Reproservice, 1-13

David, W.C. (2017). Pemasaran Strategis. Jakarta: Erlangga

Dirgantoro, C. (2016). Manajemen Stratejik Konsep, Kasus dan Implementasi. Jakarta: Grasindo Dunk, A.S. (2017). Assessing the Effects of Product Quality and Environmental Management Accounting on the Competitive Advantage of Firms. The Australasian Accounting Business \& Finance Journal 1(1), 28-38

Faidah, A.N., Nurussakinah, F., \& Supriyanto, A. (2018). Pengaruh Kualitas Produk dan Inovasi Produk Terhadap Keunggulan Bersaing (Studi Pada Industri Sasirangan di Wilayah Kota Banjarmasin). Jurnal Ilmu Manajemen Indonesia 1(1), 39-54

Ghozali, I. 2015. Aplikasi Analisis Multivariate dengan Program SPSS. Edisi ketujuh. Semarang: Badan Penerbit Universitas Diponegoro

Istiatin, Suparni, I., \& Pawenang, S. (2019). Kompetensi Pemasar, Kualitas Produk dan Kualitas Layanan Terhadap Pembelian Ulang dengan Moderasi Kepuasan Konsumen (Studi Kasus Xsavay Advertising Solo). Jurnal Manajemen 5(2), 161-170

Kadarningsih, A. (2014). Keunggulan Bersaing ; Faktor-Faktor yang Mempengaruhi dan Dampaknya Pada Kinerja Selling-In (Studi Pada Outlet Binaan PT. Indosat Semarang). Media Ekonomi \& Tekonologi Informasi 21(1), 1-18

Kotler, P. ,\& Armstrong. (2015). Prinsip-Prinsip Pemasaran. Jakarta: Erlangga

Kurniawan, F.O. (2015). Analisis Faktor-Faktor yang Mempengaruhi Keunggulan Bersaing Produk Terhadap Kinerja Penjualan. Jurnal Sains Pemasaran Indonesia 4(1), 17-30

Lenggogeni, L., \& Ferdinand, A.T. (2016). Faktor-Faktor yang Mempengaruhi Keunggulan Bersaing dalam Upaya Meningkatkan Keputusan Pembelian. Diponegoro Journal of Management 5(3), 1-12

Nasution, M.N. (2015). Manajemen Mutu Terpadu (Total Quality Management). Bogor: Ghalia Indonesia

Priyono, A. (2017). Pengaruh Green Marketing dan Identitas Merek pada Citra Merek terhadap Pengambilan Keputusan Pembelian Produk Ultra Milk di Area Pemasaran Jakarta. Industrial Engineering Journal 6(1), 4-9

Rypakova, et al. (2017). Green Marketing as the Source of the Competitive Advantage of the Business. Sustainability, 1-13

Schiffman, \& Kanuk. (2014). Perilaku Konsumen. Jakarta: Salemba Empat

Simamora, B. (2014). Panduan Riset Perilaku Konsumen. Jakarta: PT Gramedia Pustaka Utama

Singh, M. (2013). Product Quality for Competitive Advantage In Marketing. International Journal of Business and Management Invention 2(6), 5-8

Sriono, Aji, A., dan Sudaryanto. (2017). Pengaruh Pemasaran Hijau Terhadap Citra Merek dan Keputusan Membeli Air Mineral Ades Pada Mahasiswa di Jember. Prosiding Seminar Nasional dan Call For Paper Ekonomi dan Bisnis, 348-352

Sugiyono. 2016. Metode Penelitian Manajemen. Bandung: Alfabeta 
Tjiptono, F. (2018). Service Management Mewujudkan Layanan Prima. Yogyakarta: Andi Triton, P.B. (2016). Manajemen Strategis. Jakarta Selatan: Oryza

Wahyudin, N. (2015). Analisis Faktor-Faktor yang Mempengaruhi Keunggulan Bersaing untuk Meningkatkan Kinerja Perguruan Tinggi Swasta (PTS) Pada Sekolah Tinggi dan Akademi di Semarang. Holistic Journal of Management Research 3(2), 77-93

Widiarsa, I.B.I.S., \& Sulistyawati, E. (2018). Peran Keunggulan Kompetitif Memediasi Pengaruh Green Marketing Terhadap Keputusan Pembelian (Studi Pada Perusahaan Earth Café di Seminyak). E-Jurnal Manajemen Unud 7(7), 3442-3470

Yuliana, S. (2014). Pengaruh Inovasi dan Kualitas Produk Terhadap Keunggulan Bersaing Pada PD. Cap Ikan Tawes Cikoneng. Artikel Ilmiah Universitas Siliwangi, 1-13 